\title{
Detection of Hepatitis B Virus in Serum Using Amplification of Viral DNA by Means of the Polymerase Chain Reaction
}

\author{
Ryo Sumazaki, Manfred Motz, Hans Wolf, Jutta Heinig, Wolfgang Jilg, and Friedrich Deinhardt \\ Max von Pettenkofer Institute for Hygiene and Medical Microbiology, University of Munich, Munich, Federal \\ Republic of Germany
}

\begin{abstract}
A new assay was developed for the detection of hepatitis $B$ virus (HBV) in human serum using amplification of a short viral DNA sequence by means of the polymerase chain reaction. As little as $0.4 \mathrm{fg}$ viral DNA, corresponding to about 130 genome equivalents, per $\mathrm{ml}$ serum could be detected after the amplification procedure. This assay detected viral DNA in a number of patients with proven or suspected chronic HBV infection who were all negative for HBV DNA in the conventional hybridisation assay. We found $\mathrm{HBV}$ DNA in all of six $\mathrm{HBeAg}$-positive and in three of eight $\mathrm{HBeAg}$-negative $\mathrm{HBsAg}$ carriers, as well as in all of 11 patients with chronic liver disease with antibodies against the HBV core antigen (anti-HBc) as the sole marker for HBV infection, and in three of five apparently healthy individuals showing only anti HBc. Thus, this method is an important improvement for the diagnosis of persistent HBV infections, especially in patients where a definitive serological diagnosis is not possible.
\end{abstract}

KEY WORDS: DNA hybridisation, chronic HBV infection, diagnosis of persistent HBV infection

\section{INTRODUCTION}

Information about the presence or absence of hepatitis $B$ virus (HBV) in the serum of an infected individual is desirable in several instances: for the assessment of disease activity in persistent infection, for monitoring therapeutic trials of antiviral agents, or for the evaluation of the infectivity of an individual's blood. The hepatitis B surface antigen (HBsAg) is the primary marker for the diagnosis of acute or chronic hepatitis B infection; however, although its presence is bound to the presence of viral genomic material in the liver, it correlates only roughly with viral replication and with the presence of infectious particles in the circulation. The hepatitis $\mathrm{B}$ e antigen $(\mathrm{HBeAg})$ is a clearly better but also indirect marker for the presence of virus in the blood. By far the best diagnostic parameter in this respect is the viral DNA, which can be detected by a sensitive direct hybridisation assay [Bonino et al., 1981; Berninger et al., 1982]. The introduction of this test was one of the major improvements for the diagnosis of hepatitis B. It has not only led to a better understanding of the pathogenesis of the disease, especially of chronic HBV infection, but it is to date the most sensitive assay for the detection and assessment of the infectivity of an HBV-infected individual |Zyzik et al., 1986]. However, even this method has a detection limit of $10^{5}-10^{6}$ virus particles per $\mathrm{mI}$, which makes the exclusion of infectivity impossible; indeed, the infectivity of blood units determined negative for HBV DNA by the hybridisation assay could clearly be demonstrated [Krogsgaard et al., 1986]. Recently, a highly sensitive and specific method for the detection of DNA using enzymatic amplification of DNA sequences was introduced, which allows the detection of even a single copy of a gene |Saiki et al., 1985; Mullis and Faloona, 1987]. This test, known as polymerase chain reaction (PCR), was used initially to diagnose genetic abnormalities [Saiki et al., 1985; Verlaan-de Vries et al., 1986; Kogan et al., 1987], but has now also been adapted for the detection of viral pathogens, such as papilloma virus [Shibata et al., 1988], human immunodeficiency virus [Kwok et al., 1987; Loche and Mach, 1988; Laure et al., 1988], and hepatitis B virus [Larzul et al., 1988]. The use of the thermostable polymerase of the bacterium Thermus aquaticus (Taq) [Saiki et al., 1988] instead of the Klenow polymerase originally used [Saiki et al., 1985] greatly simplified this method and allowed its application for routine diagnostic procedures with large numbers of samples. Using this

Accepted for publication November 24, 1988.

Address reprint requests to Dr. Wolfgang Jilg, Max von Pettenkofer Institute for Hygiene and Medical Microbiology, University of Munich, Pettenkofer Straße 9a, D-8000 Munich 2, FRG. 
technique, we developed a sensitive and highly specific test for the detection of HBV DNA in serum. In this paper we describe our initial findings with this new assay.

\section{PATIENTS, MATERIALS, AND METHODS}

Blood samples were obtained from chronic $\mathrm{HBsAg}$ carriers, patients with chronic liver disease of unknown etiology, healthy individuals previously infected with hepatitis B with antibodies against $\mathrm{HBsAg}$ (anti-HBs) and against the core antigen of HBV (anti$\mathrm{HBc}$, healthy persons with anti-HBc only, and healthy controls without any HBV marker.

HBV DNA was isolated from $250 \mu 1$ serum by the method of Berninger et al. |1982| and dissolved in $20 \mu \mathrm{l}$ $0.01 \mathrm{M}$ Tris, 0.001 M EDTA, pH 7.4 (TE buffer).

Oligonucleotide primers were selected from conserved regions of the core gene of HBV according to the nucleotide sequence published by Ono et al. [1983]: primer I (5'): CTGTGGAGTTACTCTCGTTTTTGC (position 1937-1960); primer II (3'): CTAACATTGAGATTCCCGAGATTGAGA (position 2434-2460). They were synthesized with a Biosearch 8700 DNA synthesizer (Biosearch, San Raffael, CA).

Amplification of HBV DNA was carried out by the polymerase chain reaction using a commercially available reagent kit (Gene Amp ${ }^{\mathbb{4} \Phi}$ DNA amplification kit, Perkin Elmer, Überlingen, FRG) according to the manufacturers' instructions. Two microliters of purified DNA were used for each assay; concentration of the oligonucleotide primers was $0.5 \mu \mathrm{M}$. Prior to the addition of the Taq polymerase, samples were heated to $100^{\circ} \mathrm{C}$ for $10 \mathrm{~min}$. Thereafter the mixture was cooled down to $37^{\circ} \mathrm{C}$ and $2.5 \mathrm{U}$ of Taq polymerase in $0.5 \mu \mathrm{l}$ were added. Incubation conditions were $37^{\circ} \mathrm{C}$ for $2 \mathrm{~min}$ (annealing), $70^{\circ} \mathrm{C}$ for $3 \mathrm{~min}$ (DNA synthesis), and $92^{\circ} \mathrm{C}$ for $1 \mathrm{~min}$ (denaturation). After ten such cycles the annealing temperature was increased to $50^{\circ} \mathrm{C}$ for another 30 cycles. After the amplification procedure $10 \mu \mathrm{l}$ of sample were mixed with $1 \mu \mathrm{l}$ gel loading buffer containing $50 \%$ sucrose, $0.05 \mathrm{M}$ EDTA, $0.5 \mathrm{mg} / \mathrm{ml}$ xylene cyanol and $0.5 \mathrm{mg} / \mathrm{ml}$ bromophenol blue. Agarose gel electrophoresis on a $2 \%$ gel according to standard procedures [Maniatis et al., 1982] was then carried out. DNA was visualized by staining with ethidium bromide and transferred to a nylon membrane (Biodyne $0.2 \mu$ pore size, Pall BioSupport division, NY) according to Southern [1975]. HBV-specific sequences were detected by hybridisation with an $\alpha-{ }^{32}$ P-labelled DNA probe specific for the region between the two primers. For the generation of this probe we used a 422 base pairs long fragment (nucleotide 1986-2408) [Ono et al., 1983 !, which was obtained by digestion of HBV DNA by the restriction enzyme $\mathrm{Bgl}$ II and was subcloned into a pUC8 vector using standard methods [Maniatis et al., 1982]. The fragment was purified by agarose gel electrophoresis and used as template for the synthesis of labelled DNA by the method of "oligolabelling" | Feinberg and Vogelstein, 1983| with a "random primed
DNA labelling kit" (Boehringer Mannheim, FRG) according to the manufacturer's instructions.

For the direct detection of HBV DNA in serum without prior amplification the hybridisation assay described by Scotto et al. [1983] was used as modified by Zyzik et al. [1986]. HBV DNA was visualized using a RNA probe generated from total HBV DNA cloned into the plasmid pSP65. The radiolabelled probe was prepared with the SP6-Riboprobe ${ }^{\circledR}$ system as described by the manufacturer (Promega Biotec, Madison, WI). The detection limit of this test is about $0.3 \mathrm{pg}$ of HBV DNA.

Tests for $\mathrm{HBsAg}$, anti-HBs, anti-HBc, $\mathrm{HBeAg}$, and antibodies against $\mathrm{HBeAg}$ (anti-HBe) were performed by radioimmunoassay using commercially available kits (Abbott Laboratories, North Chicago, IL).

\section{RESULTS}

The sensitivity of the new HBV DNA assay was evaluated by testing serial dilutions of a plasmid containing the entire HBV DNA (Fig. 1). After 30-40 cycles of the PCR, $0.01 \mathrm{fg}$ of HBV DNA was clearly detected by Southern blot analysis. As little as 1 fg DNA was visible after amplification in the ethidium-bromidestained agarose gel. Accordingly, the minimum detectable HBV DNA concentration in serum should be about $0.4 \mathrm{fg} / \mathrm{ml}$, taking the concentration step during the DNA preparation and the amount of material used for the PCR $(2 \mu \mathrm{l})$ into consideration.

The clinical significance of the new assay could be demonstrated by the evaluation of a panel of sera which all had been found negative with the conventional DNA test (Table I). Six individuals who were $\mathrm{HBsAg}$ and $\mathrm{HBeAg}$ positive were found to be DNA positive after the amplification procedure, whereas of eight $\mathrm{HBeAg}$-negative $\mathrm{HBsAg}$ carriers only three showed HBV DNA after the PCR. All of the carriers were asymptomatic. Analysis of sera of 11 patients with chronic liver disease who showed ant $\mathrm{i}-\mathrm{HBc}$ as the only marker of $\mathrm{HBV}$ infection revealed that all were DNA-positive (Fig. 2); on the other hand DNA was detectable only in three of five healthy individuals with anti-HBc only. Ten healthy persons infected previously with hepatitis $B$ and ten individuals without any serological indication of an HBV infection served as controls; all were negative for HBV DNA. All these results were obtained by the Southern blot procedure; however, most of the positive sera were detectable already on the agarose gel electrophoresis.

\section{DISCUSSION}

We established a new assay for the detection of HBV in serum using the PCR for amplification of an HBV DNA sequence 524 base pairs long, which was then identified by agarose gel electrophoresis and Southern blotting. This test detects about $0.4 \mathrm{fg}$ HBV DNA, or about 130 viral particles, per $\mathrm{ml}$ serum, showing a nearly 1,000-fold higher sensitivity than the direct hybridisation assay, which has a detection limit of about $0.3 \mathrm{pg} \mathrm{HBV} \mathrm{DNA}$, corresponding to $10^{5}$ genome equiv- 


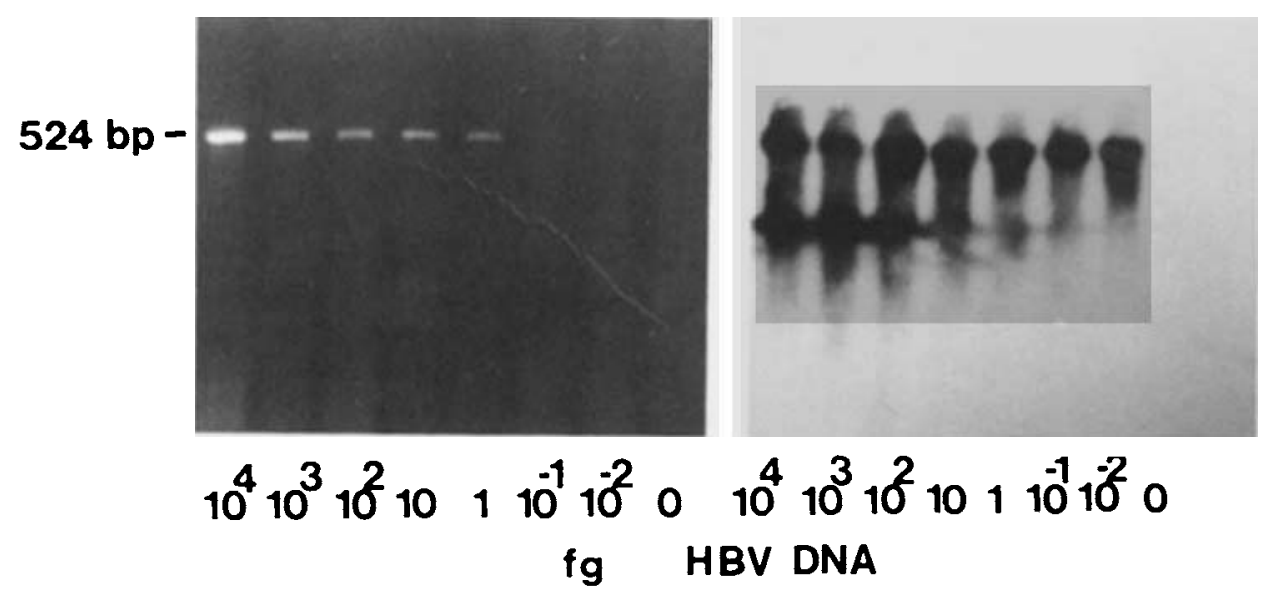

Fig. 1. Detection of HBV DNA in serial dilutions of a plasmid containing the entire HBV DNA; the amount of DNA which was amplified is indicated. The electrophoretic (left) and the Southern blot (right) analysis of the amplified 524 base pairs long DNA sequence is shown.

TABLE I. Evaluation of Sera of Controls and Individuals With Different Forms of HBV Infection for HBV DNA by the PCR Amplification Procedure*

\begin{tabular}{|c|c|c|c|}
\hline \multirow[b]{3}{*}{ Serological status } & \multicolumn{3}{|c|}{ No. subjects } \\
\hline & \multirow[b]{2}{*}{ Total } & \multicolumn{2}{|c|}{ DNA after PCR } \\
\hline & & Positive & Negative \\
\hline $\mathrm{HBsAg}$ & & & \\
\hline $\mathrm{HBeAg}^{+}$, anti-HBe & 6 & 6 & 0 \\
\hline $\mathrm{HBsAg}^{+}$ & & & \\
\hline $\mathrm{HBeAg}$, anti-HBe & 1 & 0 & 1 \\
\hline $\mathrm{HBsAg}^{+}$ & & & \\
\hline $\mathrm{HBeAg}$, anti-HBe & 7 & 3 & 4 \\
\hline $\begin{array}{l}\text { Only anti-HBc }{ }^{\dagger} \text {, } \\
\text { chronic liver disease }\end{array}$ & 11 & 11 & 0 \\
\hline Only anti-HBc ${ }^{+}$ & & & \\
\hline healthy & 5 & 3 & 2 \\
\hline Anti-HBs ${ }^{+}$, anti-HBc ${ }^{\circ}$ & 10 & 0 & 10 \\
\hline No HBV marker & 10 & 0 & 10 \\
\hline
\end{tabular}

*All sera were negative for DNA with the conventional hybridisation assay.

alents per ml [Zyzik et al., 1986]. Thus, the sensitivity of our test is comparable to that of a similar assay described recently by Larzul et al. [1988]. The specificity of the test is guaranteed 1) by the use of Southern blotting showing the correct molecular weight of the amplified sequence, and 2) by using as probe a DNA sequence between the two primers which excludes the possibility of a false positive reaction due to hybridisation with primer sequences.

Sera of $\mathbf{4 0}$ individuals with markers of a previous HBV infection and sera of ten healthy controls without any markers of hepatitis $B$ were analysed for the presence of HBV DNA by this assay. All sera were negative for HBV DNA in a conventional direct hybridisation test. After amplification the presence of HBV DNA could be demonstrated unequivocally in the majority of apparently healthy $\mathrm{HBsAg}$ carriers including all
$\mathrm{HBeAg}$-positive individuals, and in 11 patients with chronic liver disease with anti-HBc as the only marker of hepatitis B infection; in addition HBV DNA was found in three of five healthy individuals who were only anti-HBc positive.

These results show the high sensitivity of the new assay and demonstrate its usefulness for the diagnosis of different forms of HBV infection. Furthermore, our findings confirm and expand results of investigations using the conventional hybridisation assay for the detection of HBV DNA. These earlier studies showed that viral replication, as demonstrated by the presence of viral DNA in the circulation, is correlated with the presence of $\mathrm{HBeAg}$ and with symptomatic liver disease [Bonino et al., 1981; Berninger et al., 1982; Scotto et al., 1983; Zyzik et al., 1986]. Our data fit well into this pattern. All $\mathrm{HBeAg}$-positive individuals tested were indeed also DNA positive, although they were apparently asymptomatic. These cases were selected for the amplification procedure because they were negative in the conventional hybridisation assay, which is positive in the vast majority of $\mathrm{HBeAg}$-positive carriers; thus, this result could well mean that all $\mathrm{HBeAg}$-positive HBsAg carriers are viremic. Even more important seems our finding that all patients with chronic liver disease showing anti-HBc as the only $\mathrm{HBV}$ marker were DNA positive, as well as three of five healthy individuals showing this serological profile. Using the direct hybridisation assay, Seelig et al. |1985| could detect HBV DNA in 9 of 50 patients with liver disease showing this pattern, whereas Brechot et al. [1985] were unable to demonstrate HBV DNA in the serum of 11 similar patients, although 9 of them had HBV DNA in their livers. Healthy individuals with anti-HBc only were found to be HBV DNA negative in the direct hybridisation assay by most authors [Scotto et al., 1983; Zyzik et al., 1986], nevertheless it is known from several studies that at least some of these individuals are 


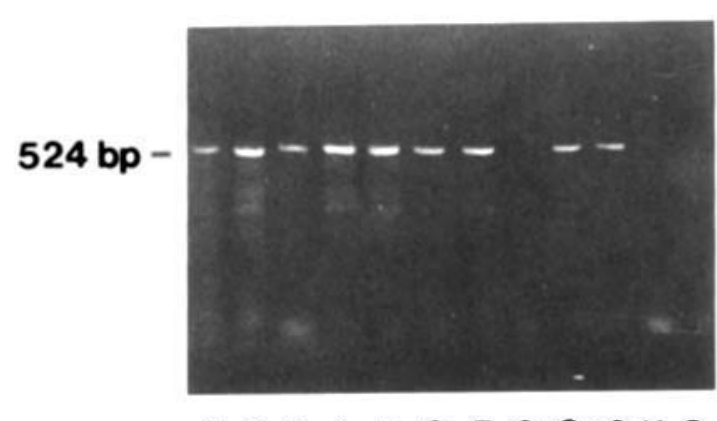

8

12345678910110

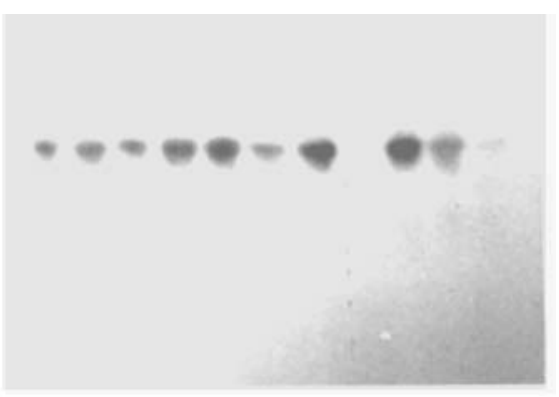

12345678910110

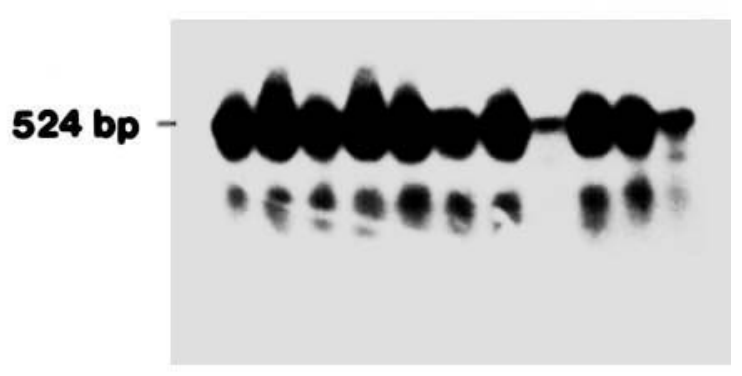

b

12345678910110

Fig. 2. Analysis of sera of 11 patients $(1-11)$ with chronic liver disease and anti-HBc as the sole serological marker. 0 =: negative control. a: Electrophoretic (left) and Southern blot (right) analysis of the amplified sequence; exposure time was $2 \mathrm{~h}$. b: Same Southern blot as in panel a but exposed for $8 \mathrm{hr}$. showing clear positive signals for sera 8 and 11 .

chronic carriers of HBV (the so-called low-level carriers) and are able to transmit the infection via blood transfusions [Hopkins et al., 1982; Sugg et al., 19821. Such individuals can be well identified by the procedure described here. Thus, the detection of HBV DNA after amplification by PCR may become an indispensable method to clarify the extent of HBV infection in cases were a definitive serological diagnosis is not possible, e.g., where anti-HBc is the sole serological marker for hepatitis $B$ infection.

\section{REFERENCES}

Berninger M, Hammer M, Hoyer B, Gerin GL (1982): An assay for the detection of the DNA genome of hepatitis $B$ virus in serum. Journal of Medical Virology 9:57-68.

Bonino F, Hoyer B, Nelson J, Engle R, Verme G, Gerin J (1981): Hepatitis B virus DNA in the sera of $\mathrm{HBsAg}$ carriers: A marker of active hepatitis $B$ virus replication in the liver. Hepatology $1: 386-$ 391.

Brechot C, Degos F, Lugassy C, Thiers V, Zafrani S, Franco D, Bismuth $H$, Trepo C, Benhamou JP, Wands J, Isselbacher $K$, Tiollais $P$ Berthelot P (1985): Hepatitis $B$ virus DNA in patients with chronic liver disease and negative tests for hepatitis $B$ surface antigen. New England Journai of Medicine 312:270-276.

Feinberg AP, Vogelstein B (1983): A technique for radiolabeling DNA restriction endonuclease fragments to high specific activity. Analytical Biochemistry 132:6-13

Hopkins R, Kane E, Robertson AE, Haase G (1982): Hepatitis B virus transmitted by $\mathrm{HBsAg-negative} \mathrm{blood} \mathrm{containing} \mathrm{anti-HBc.} \mathrm{Med-}$ ical and Laboratory Science 39:61-62.

Kogan SC, Doherty M, Gitschier J (1987): An improved method for prenatal diagnosis of genetic diseases by analysis of amplified DNA sequences. New England Journal of Medicine 317:985-990.

Krogsgaard K, Wantzin P, Aldershvile J, Kryger P, Andersson P, Nielsen JO \{1986): Hepatitis B virus DNA in hepatitis B surface antigen-positive blood donors: Relation to the hepatitis B e system and outcome in recipients. Journal of Infectious Diseases 153:298303.

Kwok S, Mack DH, Mullis KB, Poiesz B, Ehrlich G, Blair D, Friedman-Kien A. Sninsky JJ (1987): Identification of human immunodeficiency virus sequences by using in vitro enzymatic amplification and oligomer cleavage detection. Journal of Virology 61: $1690-1694$

Larzul D. Guigue F, Sninsky JJ, Mack DH, Brechoe C, Guesdon JL, (1988): Detection of hepatitis B sequences in serum by using in vitro enzymatic amplification. Journal of Virological Methods 20:227-237

Laure F, Courgnaud V, Rouzioux C, Blanche S, Veber V, Burgard M, Jacomet C, Griscelli C, Brechot C (1988): Detection of HIV I DNA in infants and children by means of the polymerase chain reaction. Lancet 2:538-541.

Loche M, Mach B (1988): Identification of HIV-infected seronegative individuals by a direct diagnostic test based on hybridisation to ampiified viral DNA. Lancet 2:418-421.

Maniatis T, Fritsch EF, Sambrock J (1982): "Molecular Cloning-A Laboratory Manual." Cold Spring Harbor, NY: Cold Spring Harbor Laboratory.

Mullis K, Faloona FA (1987): Specific synthesis of DNA in vitro via a polymerase-catalysed chain reaction. Methods in Enzymology 155:335-350.

Ono Y, Onda H, Sasada R, Igarashi K, Sugino Y, Nishioka K (1983) The complete nucleotide sequences of the cloned hepatitis $B$ virus DNA; subtype adr and adw. Nucleic Acids Research 11:17471757 .

Saiki RK, Gelfand DH, Stoffel S, Scharf SJ, Higuchi R, Horn GT, Mullis KB, Erlich GT (1988): Primer-directed enzymatic amplifi- 
cation of DNA with a thermostable DNA polymerase. Science 239:487-491.

Saiki R, Scharf S, Faloona F, Mullis K, Horn G, Erlich HA, Arnheim $N$ (1985): Enzymatic amplification of $\beta$-globin genomic sequences and restriction site analysis for diagnosis of sickle cell anemia. Science 230:1350-1353.

Scotto J, Hadchouel M, Hery C, Yvart J, Tiollais P, Brechot C (1983): Detection of hepatitis B virus DNA in serum by a simple spot hybridisation technique. Comparison with results for other viral markers. Hepatology 3:279-284.

Seelig R, Metzger B, Renz M, Metzger P, Seelig HP (1985): Diagnostische Bedeutung des Nachweises von Hepatitis-B-Virus-DNS bei akuten und chronischen Hepatitiden. Deutsche Medizinische Wochenschrift 110:1968-1974.

Shibata DK, Arnheim N, Martin WJ (1988): Detection of human pap- illoma virus in paraffin-embedded tissue using the polymerase chain reaction. Journal of Experimental Medicine 167:225-230.

Southern EM (1975): Detection of specific sequences among DNA fragments separated by gel electrophoresis. Journal of Molecular Biology 98:503-517.

Sugg U, Ehrhardt S, Schneider W (1982): Chronic "low-level" hepatitis $B$ virus carrier with probable infectivity. The Lancet i:446447.

Verlaan-de Vries M, Bogaard ME, van den Elst H, van Boom JH, van der Eb AJ, Bos JL (1986): A dot-blot screening procedure for mutated ras oncogenes using synthetic oligodeoxynucleotides. Gene 50:313-320.

Zyzik E, Gerlich WH, Uy A, Köchel H, Thomssen R (1986): Assay of hepatitis $B$ virus genome titers in sera of infected subjects. European Journal of Clinical Microbiology 5:330-335. 